medRxiv preprint doi: https://doi.org/10.1101/2021.07.14.21256113; this version posted July 18, 2021. The copyright holder for this preprint

(which was not certified by peer review) is the author/funder, who has granted medRxiv a license to display the preprint in perpetuity.

All rights reserved. No reuse allowed without permission.

\title{
Racial Inequalities in Alcohol Use Disorder Diagnosis in a Sample of 700,000 Veterans
}

\author{
Rachel Vickers-Smith, ${ }^{1,2,3}$ Amy C. Justice, ${ }^{4,5}$ William C. Becker, ${ }^{4,5}$ Christopher T. Rentsch, ${ }^{5,6}$
} Brenda Curtis, ${ }^{7}$ Anita Fernander, ${ }^{8}$ Emily E. Hartwell, ${ }^{1,9}$ Eseosa T. Ighodaro, ${ }^{10}$ Rachel L. Kember, ${ }^{1,9}$ Janet Tate, ${ }^{4,5}$ Henry R. Kranzler ${ }^{1,9}$

\footnotetext{
${ }^{1}$ Mental Illness Research, Education and Clinical Center, Veterans Integrated Service Network 4, Philadelphia, PA 19104

${ }^{2}$ Department of Epidemiology, University of Kentucky College of Public Health, Lexington, KY 40536

${ }^{3}$ Center on Drug and Alcohol Research, Department of Behavioral Science, University of Kentucky College of Medicine, Lexington, KY 40536

${ }^{4}$ Yale School of Medicine, New Haven, CT 06511

${ }^{5}$ Veterans Affairs Connecticut Healthcare System, West Haven, CT 06516

${ }^{6}$ Faculty of Epidemiology and Population Health, London School of Hygiene \& Tropical Medicine, London, UK WC1E 7HT

${ }^{7}$ National Institute on Drug Abuse Intramural Research Program, Baltimore, MD 21224

${ }^{8}$ Department of Behavioral Science, University of Kentucky College of Medicine, Lexington, KY 40536

${ }^{9}$ University of Pennsylvania Perelman School of Medicine, Philadelphia, PA 19104

${ }^{10}$ Department of Neurology, Mayo Clinic, Rochester, MN 55901
}

\section{Correspondence to:}

Rachel Vickers-Smith, PhD, MPH

Assistant Professor

Department of Epidemiology

College of Public Health

University of Kentucky

111 Washington Avenue

Lexington, Kentucky 40536

Email: rachel.vickers@uky.edu

Acknowledgements: We thank all US Veterans for their service and particularly those Veterans who participated in the Million Veteran Program. This research is based on data from the Million Veteran Program, Office of Research and Development, Veterans Health Administration, and was supported by award \#I01 BX003341 and the Veterans Integrated Service Network 4 Mental Illness Research, Education and Clinical Center. This publication does not represent the views of the Department of Veteran Affairs or the United States Government. This research was supported in part by the Intramural Research Program of the NIH, NIDA.

Disclosure: Dr. Kranzler is a member of an advisory board for Dicerna Pharmaceuticals, a consultant to Sophrosyne Pharmaceuticals, and a member of the American Society of Clinical Psychopharmacology's Alcohol Clinical Trials Initiative, which was supported in the last three years by AbbVie, Alkermes, Dicerna, Ethypharm, Indivior, Lilly, Lundbeck, Otsuka, Pfizer, Arbor, and Amygdala Neurosciences. Dr. Kranzler is named as an inventor on PCT patent 
medRxiv preprint doi: https://doi.org/10.1101/2021.07.14.21256113; this version posted July 18, 2021. The copyright holder for this preprint (which was not certified by peer review) is the author/funder, who has granted medRxiv a license to display the preprint in perpetuity.

All rights reserved. No reuse allowed without permission.

application \#15/878,640 entitled: "Genotype-guided dosing of opioid agonists," filed January 24, 2018. The other authors have no disclosures to make. 
medRxiv preprint doi: https://doi.org/10.1101/2021.07.14.21256113; this version posted July 18, 2021. The copyright holder for this preprint

\begin{abstract}
Background: Studies show that Black and Hispanic Veterans have a higher prevalence of alcohol use disorder (AUD) than White Veterans. We examined whether the relationship between self-reported race/ethnicity and AUD diagnosis varies by self-reported alcohol consumption.
\end{abstract}

Methods: The sample included 700,013 Black, Hispanic, and White Veterans enrolled in the Million Veteran Program cohort. Alcohol consumption was defined as an individual's maximum score on the Alcohol Use Disorders Identification Test-Consumption (AUDIT-C) questionnaire, a screen for hazardous or harmful drinking. The primary outcome, AUD, was defined by the presence of ICD-9/10 codes in the electronic health record. We used logistic regression with interactions to assess the association between race/ethnicity and AUD by maximum AUDIT-C score.

Results: Black and Hispanic Veterans were more likely to have an AUD diagnosis than White Veterans despite similar levels of alcohol consumption. The difference was greatest between Black and White men. At all but the lowest and highest levels of alcohol consumption, Black men had 24\%-111\% greater odds of an AUD diagnosis. The association between race/ethnicity and AUD diagnosis remained after adjustment for alcohol consumption, alcohol-related disorders, and other potential confounders.

Conclusions: The large discrepancy in AUD diagnosis across groups despite a similar distribution of alcohol consumption measures suggests that Veterans are differentially assigned an AUD diagnosis by race/ethnicity. Efforts are needed to examine the causes of the observed differences and to implement changes, such as structured diagnostic methods, to address a likely contributor to racial differences (i.e., bias) in AUD diagnosis. 
medRxiv preprint doi: https://doi.org/10.1101/2021.07.14.21256113; this version posted July 18, 2021. The copyright holder for this preprint (which was not certified by peer review) is the author/funder, who has granted medRxiv a license to display the preprint in perpetuity.

All rights reserved. No reuse allowed without permission.

\section{Introduction}

Clinical diagnosis is a foundation of decision making and treatment. ${ }^{1}$ Clinical "labels," can produce lasting stigma and when inappropriate can cause lasting damage. ${ }^{2,3}$ Further, misdiagnosis (i.e., over or under diagnosis, misidentification) can result in ineffective treatment, inaccurate prognostic assessments, poor outcomes, and mistrust in the healthcare system. ${ }^{4,5}$ For diagnosing behavior-based conditions, factors that can influence diagnosis include multiple medical conditions, varying symptom presentation, provider's level of education and experience, the patient's willingness to disclose symptomatology, cultural factors, and the application of standard criteria or assessments. ${ }^{6}$ The race or ethnicity of a patient and patient-provider racial/ethnic discordance, can also influence diagnostic decisions through implicit bias, ${ }^{4,7,8}$ i.e., healthcare providers' unconscious prejudices or stereotypes that impacts clinical judgment or treatment. $^{9,10}$

Studies in the Veterans Health Administration of the Department of Veterans Affairs (VA) have shown that, compared to White Veterans, Black and Hispanic Veterans have a higher rate of clinically recognized alcohol use disorder (AUD) ${ }^{11}$ and Black Veterans are more likely to be identified as needing an intervention ${ }^{12,13}$ and to receive psychosocial interventions, ${ }^{12,14}$ but less likely to receive pharmacotherapy for AUD. ${ }^{15}$ One potential explanation for the observed disparities is that the groups have different alcohol consumption patterns. ${ }^{16}$

Here, we examine the contribution of self-reported alcohol consumption to the likelihood of receiving an AUD diagnosis among Black, Hispanic, and White Veterans. To facilitate the identification of individuals with at-risk or harmful drinking, beginning in 2008 the VA has routinely screened primary care patients using the AUDIT-C ${ }^{17,18}$ (the first three items of the 10item Alcohol Use Disorders Identification Test ${ }^{19}$ ). We examined the association of AUDIT-C 
medRxiv preprint doi: https://doi.org/10.1101/2021.07.14.21256113; this version posted July 18, 2021. The copyright holder for this preprint (which was not certified by peer review) is the author/funder, who has granted medRxiv a license to display the preprint in perpetuity.

All rights reserved. No reuse allowed without permission.

scores with AUD diagnosis codes across the three racial/ethnic groups in a national cohort of more than 700,000 Veterans. Specifically, we evaluated: (1) the relationship between race/ethnicity and AUD diagnosis across similar levels of self-reported alcohol consumption and (2) sociodemographic and clinical correlates of an AUD diagnosis.

\section{Methods}

Due to space constraints, abbreviated methods are described below; detailed methods can be found in the Supplementary Appendix.

Study Sample

The study sample included 700,013 participants in the Million Veteran Program (MVP), an ongoing longitudinal cohort of US Veterans. ${ }^{20}$

\section{Measures}

Racelethnicity. Race/ethnicity was self-reported as non-Hispanic White (White), nonHispanic Black (Black), and Hispanic. Participants who self-identified as Hispanic were so classified irrespective of their race, consistent with the U.S. Census Bureau. ${ }^{22}$

Self-reported alcohol consumption. The AUDIT-C is a valid, reliable screening instrument that is routinely used to identify individuals with hazardous or harmful drinking. ${ }^{17,18}$ Maximal reported alcohol consumption was determined using the highest AUDIT-C recorded in the EHR. We also examined the association between the maximum score on AUDIT-C item 3 (binge drinking frequency) and AUD diagnosis by race/ethnicity.

Demographics and clinical diagnoses. Sex and age at enrollment were extracted from both questionnaires and EHR data. ${ }^{21}$ Clinical diagnoses, including AUD, alcohol-related medical disorders (i.e., cirrhosis, neuropathy, cardiomyopathy, gastritis, fatty liver disease, hepatitis, and 
medRxiv preprint doi: https://doi.org/10.1101/2021.07.14.21256113; this version posted July 18, 2021. The copyright holder for this preprint (which was not certified by peer review) is the author/funder, who has granted medRxiv a license to display the preprint in perpetuity.

All rights reserved. No reuse allowed without permission.

liver damage), drug use disorder, and mental disorder, required the presence of one inpatient or two outpatient ICD-9/10 diagnostic codes in the VA EHR.

\section{Data Analysis}

All analyses were stratified by sex to account for sex-related differences. ${ }^{23}$ Descriptive statistics by racial/ethnic group were computed with means, standard deviations, and frequencies. We compared characteristics across race/ethnicity using ANOVA with Tukey's post-hoc tests, chi-square, and Fisher's exact tests. The correlation between maximum AUDIT-C score and AUD diagnosis was computed using Spearman's rho, and between binge drinking frequency and AUD diagnosis with a chi-square test. We used logistic regression to identify the factors associated with documented AUD diagnosis and assessed the interaction between race/ethnicity and maximum AUDIT-C score by creating a composite variable of the two factors. We probed significant interactions with stratified logistic regression models. Sensitivity analyses with ageadjusted mean AUDIT-C score assessed the robustness of estimates using maximum AUDIT-C scores. For all models, C-statistics served to assess discrimination. All analyses were performed using SAS 9.2 (Cary, NC), with an alpha of 0.05 to denote statistical significance.

\section{Results}

Of Veterans included in this study, $91 \%$ were men $(n=638,205)$ and $9 \%$ were women $(n=61,808)$.

\section{Men}

\section{Sample Characteristics}

The racial/ethnic distribution was White (74\%), Black (19\%), and Hispanic (7\%; Table 1). The modal maximal AUDIT-C score range was 1-3 across the three groups. Black male Veterans (BMV) had more AUDIT-C assessments (mean=9.5; SD=4.6) than Hispanic (HMV; 
medRxiv preprint doi: https://doi.org/10.1101/2021.07.14.21256113; this version posted July 18, 2021. The copyright holder for this preprint (which was not certified by peer review) is the author/funder, who has granted medRxiv a license to display the preprint in perpetuity.

All rights reserved. No reuse allowed without permission.

mean=8.3; $\mathrm{SD}=4.3$ ) or White (WMV; mean=8.8; $\mathrm{SD}=4.3$ ) male Veterans, and higher frequency of an AUD diagnosis $(33 \%, 25 \%$, and 18\%, respectively) and a drug use disorder diagnosis (29\%, 16\%, and 11\%, respectively) than HMV or WMV. Although statistically significant, differences in the prevalence of alcohol-related diagnoses across racial/ethnic groups were small. WMV had a lower frequency of a mental disorder diagnosis (47\%) than BMV (58\%) or HMV $(61 \%)$.

Association between AUDIT-C and AUD by Race/Ethnicity

The correlation between AUDIT-C and AUD diagnosis was lowest among WMV (rho=0.36; $P<0.0001)$, followed by HMV (rho=0.43; $P<0.0001)$ and BMV (rho=0.47; $P<0.0001)$. At every maximum AUDIT-C score, WMV were less likely than BMV to receive an AUD diagnosis (Figure 1a; all $P<0.0001$ ). The greatest difference was at AUDIT-C=4 (i.e., the positive screening cutoff for men), where WMV were approximately one-third as likely to have an AUD diagnosis as BMV. Although HMV had lower AUD frequency than BMV across all AUDIT-C scores, it was generally higher than among WMV, with the greatest difference also at AUDIT-C $=4(P<0.0001)$. The greatest difference between HMV and BMV was at AUDIT-C=7, where HMV were almost one-third less likely to have an AUD diagnosis than BMV $(P<0.0001)$.

BMV were significantly more likely than HMV and WMV to have an AUD diagnosis regardless of binge drinking frequency (all $P<0.0001$; Supplemental Figure 3a). Overall, HMV were more likely to have an AUD diagnosis than WMV regardless of binge drinking frequency.

\section{Multivariable Analysis}

Similar to findings from bivariate analyses, in multivariable analyses with adjustment for alcohol consumption and other potential confounders (Table 2), WMV were less likely to receive an AUD diagnosis than BMV and HMV. Post hoc analysis of the significant interaction between 
medRxiv preprint doi: https://doi.org/10.1101/2021.07.14.21256113; this version posted July 18, 2021. The copyright holder for this preprint (which was not certified by peer review) is the author/funder, who has granted medRxiv a license to display the preprint in perpetuity.

All rights reserved. No reuse allowed without permission.

race/ethnicity and AUD diagnosis by alcohol consumption (Figure 2) revealed that BMV had 24\%-111\% greater odds of an AUD diagnosis than WMV at maximum AUDIT-C $=1-10$. At AUDIT-C $=4$, BMV had over twice the odds of an AUD diagnosis as WMV $(P<0.0001)$. HMV were significantly more likely than WMV to have an AUD diagnosis at maximum AUDIT-C=24, with the highest odds at AUDIT-C $=2(P<0.0001)$.

Among men, having a drug use disorder diagnosis was associated with nearly 13-fold increased odds of an AUD diagnosis $(P<0.0001)$. Greater age, a mental disorder diagnosis, and alcohol-related medical disorders were also associated with significantly greater odds of an AUD diagnosis $(P<0.0001)$.

\section{Women}

\section{Sample Characteristics}

The racial/ethnic distribution among women was White (62\%), Black (30\%), and Hispanic (8\%; Table 1). The modal maximal AUDIT-C score range was 1-2 for each group. Black female Veterans (BFV) had more AUDIT-C assessments on average (mean=9.2; $\mathrm{SD}=4.3$ ) than Hispanic (HFV; mean=7.8; $\mathrm{SD}=4.1)$ and White (WFV; mean=8.9; $\mathrm{SD}=4.3)$ female Veterans. The frequency of an AUD diagnosis among BFV (15\%) was significantly higher than WFV or HFV (both $13 \% ; P<0.0001$ and $P=0.001$, respectively). BFV had the highest frequency (13\%) and HFV the lowest frequency (10\%) of a drug use disorder. HFV were more likely to have a mental disorder diagnosis (73\%) than BFV (71\%) and WFV (70\%). There were no significant racial/ethnic group differences in the prevalence of alcohol-related diagnoses.

\section{Association between AUDIT-C and AUD by Race/Ethnicity}

The correlation between AUDIT-C and AUD diagnosis was lower among WFV (rho=0.30; $P<0.0001)$ than HFV (rho=0.34; $P<0.0001)$ or BFV (rho=0.40; $P<0.0001)$. BFV had 
medRxiv preprint doi: https://doi.org/10.1101/2021.07.14.21256113; this version posted July 18, 2021. The copyright holder for this preprint (which was not certified by peer review) is the author/funder, who has granted medRxiv a license to display the preprint in perpetuity.

All rights reserved. No reuse allowed without permission.

the highest percentage of AUD diagnosis at nearly every level of alcohol consumption (Figure 1b) and were significantly more likely than WFV and HFV to receive an AUD diagnosis at AUDIT-C $=2$ and 4-7 (all $P<0.05$ ). At AUDIT-C=0, 1, and 7, WFV were more likely to have an AUD diagnosis than HFV. The maximal difference in the proportion of AUD diagnoses between BFV and WFV was at AUDIT-C=4 (22\% vs. $12 \% ; P<0.0001)$.

Racial/ethnic differences in the association between AUD frequency of binge drinking were less evident in women than men. BFV were more likely to receive an AUD diagnosis than HFV when reporting binge drinking weekly or less often (AUDIT-C question 3 scores=0-3; all $P \leq 0.01$; Supplemental Figure 3b).

\section{Multivariable Analysis}

The overall interaction between race/ethnicity and maximum AUDIT-C was significant $(P<0.0001)$. BFV had a higher probability of an AUD diagnosis compared to HFV and WFV at moderate AUDIT-C scores and HFV had a lower probability of an AUD diagnosis compared to BFV and WFV at higher AUDIT-C scores (Supplemental Figure 4, Table 2). A drug use disorder diagnosis was associated with over 13-fold increase in the odds of an AUD diagnosis $(P<0.0001)$. Greater age, a mental disorder diagnosis, and alcohol-related health conditions were associated with significantly greater odds of an AUD diagnosis (all $P \leq 0.001$ ).

\section{Sensitivity Analysis Using Age-Adjusted Mean AUDIT-C Score}

Using age-adjusted mean rather than maximal AUDIT-C score did not affect the findings overall or by sex (Supplemental Table 3).

\section{Discussion}

In this national cohort study of 700,000 veterans, we identified a differential frequency of AUD diagnosis by race/ethnicity. The greatest discrepancy was among Black men who, at all but 
medRxiv preprint doi: https://doi.org/10.1101/2021.07.14.21256113; this version posted July 18, 2021. The copyright holder for this preprint (which was not certified by peer review) is the author/funder, who has granted medRxiv a license to display the preprint in perpetuity.

All rights reserved. No reuse allowed without permission.

the lowest and highest levels of alcohol consumption, had 24\%-111\% greater odds of an AUD diagnosis than White men. Hispanic men had 21\%-32\% greater odds of an AUD diagnosis than White men. The prevalence of disorders associated with persistent heavy drinking (e.g., alcoholic cirrhosis and hepatitis), whose diagnosis generally relies on objective measures (e.g., laboratory values, ultrasound findings), was similar across the three groups, indicating AUD diagnosis among Black and Hispanic Veterans was not due to greater alcohol consumption than White veterans. The difference in AUD diagnosis across the groups is also not attributable to the slightly higher percentages of positive AUDIT-C screens among Black and Hispanic Veterans than White Veterans. Further, the association between race/ethnicity and AUD diagnosis remained after adjustment for alcohol consumption, alcohol-related disorders, drug use disorder, and other potential confounders.

This study used EHR data on self-reported alcohol consumption and AUD diagnosis in a sample large enough to account for a variety of potential contributing factors. The AUD frequency across race/ethnicity and sex is similar to that previously observed in the Veteran population. ${ }^{11}$ Together, these findings highlight differential clinical assessment of AUD by race/ethnicity. It is unclear whether the difference is due to an overdiagnosis of Black Veterans, underdiagnosis of White Veterans, or a combination of the two, both of which are harmful, as overdiagnosis can be stigmatizing and underdiagnosis can delay treatment. The inequitable diagnostic process occurs in the context of Black Veterans being referred and receiving alcohol treatment at higher rates than White or Hispanic Veterans, ${ }^{12,13}$ though it is unclear whether this results in better outcomes or what the potential impact is of receiving an AUD diagnosis. Further, any potential benefit of disparate treatment rates should not overshadow the central issue that racial/ethnic inequity in assessment, particularly toward Black patients, appears to exist. 
medRxiv preprint doi: https://doi.org/10.1101/2021.07.14.21256113; this version posted July 18, 2021. The copyright holder for this preprint

Studies are needed to examine the mechanism by which Veterans receive an AUD diagnosis and factors that likely affect the observed inequity such as implicit bias and systemic racism.

The greatest disparity in AUD diagnosis after adjustment for potential confounders occurred at a maximum AUDIT-C score of 3 or 4, near the cutoff for a positive AUDIT-C screen ( $\geq 4$ for men; $\geq 3$ for women). This suggests that at scores near the threshold, providers are more likely to assign a diagnosis to Black or Hispanic Veterans than White Veterans. ${ }^{7,24,25}$ In a series of experiments that evaluated implicit stereotyping, physicians were more likely to associate negative stereotypes (e.g., drug abuse, HIV) with Black than White patients, ${ }^{7,24}$ suggesting that diagnostic disparities may be due to implicit bias. Some studies have suggested that diagnostic disparities could be due to the differential presentation of psychiatric symptoms across racial and ethnic groups. ${ }^{11,26}$ While this is possible due to the impact of culture on psychiatric symptom presentation, ${ }^{27}$ it suggests that diagnostic practice references the White experience. In this study, no data were available on why a diagnosis was given, although future studies could utilize diagnostic interviews to learn whether there are differences in endorsed criteria across race/ethnicity.

We found that the presence of a drug use disorder diagnosis was highly correlated with the diagnosis of AUD. These disorders commonly co-occur, both in the $\mathrm{VA}^{28}$ and the general population. ${ }^{29,30}$ However, in nationally representative epidemiologic studies, the prevalence of concurrent alcohol and drug use does not differ substantially by race/ethnicity (Black=9\%, Hispanic $=7 \%$, White $=8 \%),{ }^{30}$ suggesting that alcohol and drug use disorder diagnoses should not differ substantially by race/ethnicity. However, in this sample, Black men were over three times and Hispanic men were nearly twice as likely to have at least one comorbid drug diagnosis as White men. One explanation for these findings could be that once a patient receives an AUD 
medRxiv preprint doi: https://doi.org/10.1101/2021.07.14.21256113; this version posted July 18, 2021. The copyright holder for this preprint (which was not certified by peer review) is the author/funder, who has granted medRxiv a license to display the preprint in perpetuity.

All rights reserved. No reuse allowed without permission.

diagnosis, providers may be more likely to query the patient about other substance use. Findings may also be due to implicit bias toward Black and Hispanic Veterans resulting in additional screening for additional substance use in these racial/ethnic populations. ${ }^{7,31,32}$ More research is needed to understand the source of these differences. Further, to aid equitable diagnosis and treatment of multiple substance use (beyond alcohol and tobacco), standardized screening and assessment are recommended.

Women were less likely than men to have an AUD diagnosis, consistent with population estimates $^{33}$ and findings among Veterans. ${ }^{34}$ Although women consume less alcohol than men, the sex/gender difference has been decreasing in recent years. ${ }^{35}$ In studies of unhealthy alcohol use, women experience greater alcohol use related stigma than men, ${ }^{36,37}$ which could impact how providers respond to ${ }^{38,39}$ and document ${ }^{40}$ use among women. More research is needed to understand sex/gender differences in substance use reporting and its documentation in the EHR.

As seen among men, at nearly every level of alcohol consumption, Black women were more likely than Hispanic and White women to receive an AUD diagnosis, despite the groups' similar distributions of alcohol consumption and prevalence of alcohol-related disorders. There were few differences in the relation between AUD frequency and alcohol consumption between Hispanic and White women. Where such differences occurred, White women had a greater AUD frequency than Hispanic women, consistent with estimates from the 2019 National Survey of Drug Use and Health where alcohol use prevalence is higher among non-Hispanic White women than Hispanic women. ${ }^{33}$

This study has several limitations. Despite obvious differences in the frequency of an AUD diagnosis by racial/ethnic group, the basis for the discrepancies cannot be ascertained using EHR data. Second, measures of alcohol consumption relied on self-report, which may not be 
medRxiv preprint doi: https://doi.org/10.1101/2021.07.14.21256113; this version posted July 18, 2021. The copyright holder for this preprint (which was not certified by peer review) is the author/funder, who has granted medRxiv a license to display the preprint in perpetuity.

All rights reserved. No reuse allowed without permission.

valid. In future studies alcohol biomarkers could serve as objective measures of alcohol use.

Lastly, findings from this study of US veterans enrolled in a genetic cohort study may not generalize to other populations, even the general Veteran population.

Our study also has a number of notable strengths. The availability of annual assessments of alcohol consumption and the availability of an informative EHR enabled the ability to analyze relationships between measures of alcohol consumption and an AUD diagnosis, as well as multiple clinical factors that could influence that association. Second, the large and diverse sample made it possible to examine factors that could affect the likelihood of an AUD diagnosis.

We identified a large difference in AUD diagnosis by race/ethnicity, which was discrepant with self-reported alcohol consumption. As other factors do not appear to explain this discrepancy, the findings suggest that there is bias in the diagnosis of AUD by race/ethnicity. These findings should encourage the VA and other healthcare systems to examine the causes of any observed differences, and to implement changes, such as the use of structured diagnostic methods, to address a likely contributor to racial differences in AUD diagnosis (i.e., bias). 
Table 1. Demographic and clinical characteristics of the sample, by sex and race/ethnicity $(n=700,013)$.

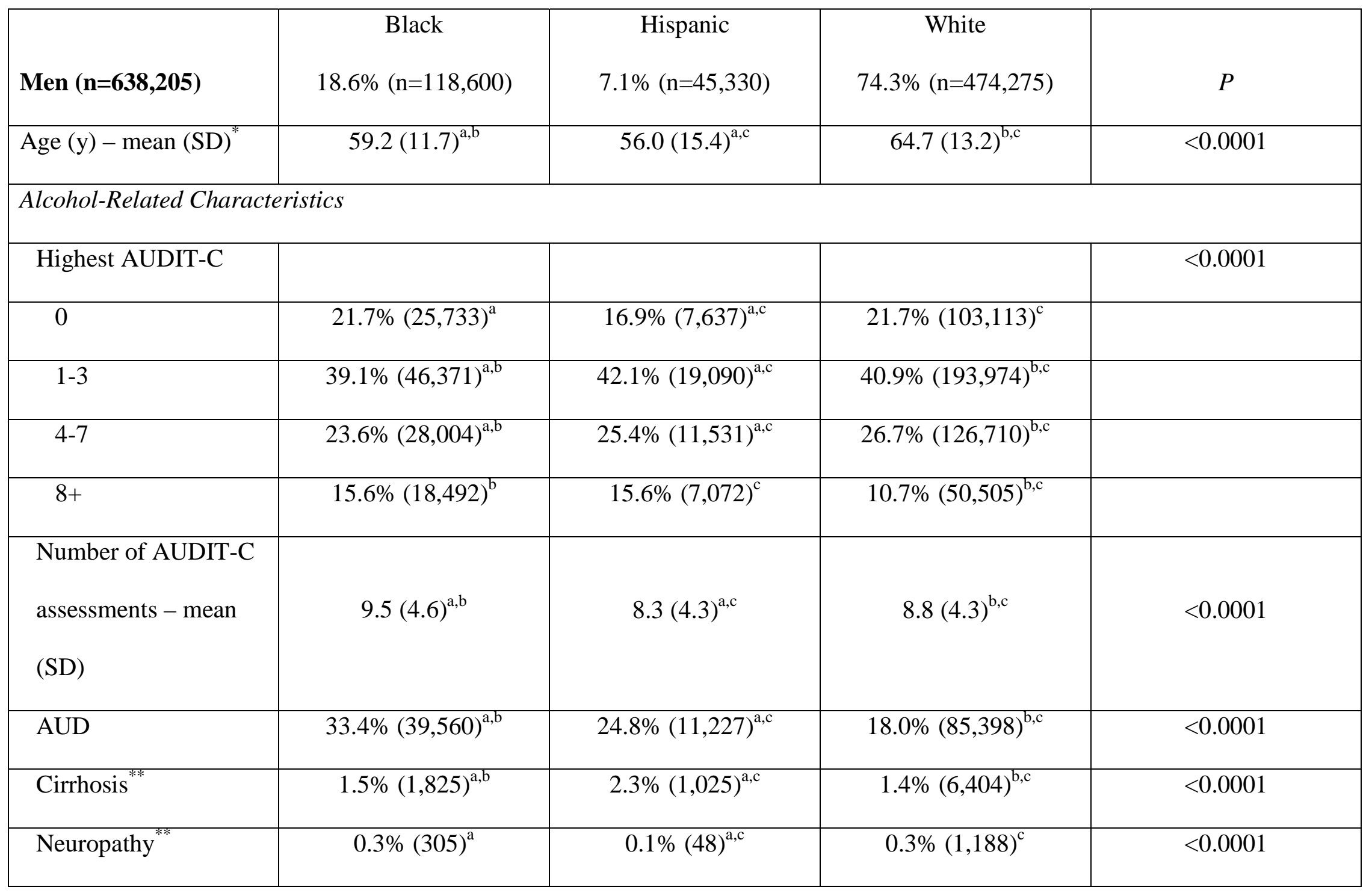




\begin{tabular}{|c|c|c|c|c|}
\hline Cardiomyopathy $^{* *}$ & $0.3 \%(395)^{\mathrm{a}, \mathrm{b}}$ & $0.1 \%(54)^{\mathrm{a}}$ & $0.2 \%(726)^{b}$ & $<0.0001$ \\
\hline Gastritis $^{* *}$ & $0.4 \%(457)^{a, b}$ & $0.3 \%(114)^{\mathrm{a}}$ & $0.2 \%(1,111)^{b}$ & $<0.0001$ \\
\hline Fatty liver disease ${ }^{* *}$ & $0.5 \%(619)^{a, b}$ & $0.7 \%(310)^{\mathrm{a}, \mathrm{c}}$ & $0.5 \%(2,209)^{b, c}$ & $<0.0001$ \\
\hline Hepatitis $^{* *}$ & $0.7 \%(842)^{b}$ & $0.7 \%(296)^{\mathrm{c}}$ & $0.5 \%(2,530)^{b, c}$ & $<0.0001$ \\
\hline Liver damage $^{* *}$ & $0.4 \%(517)^{b}$ & $0.5 \%(226)^{\mathrm{c}}$ & $0.3 \%(1,495)^{b, c}$ & $<0.0001$ \\
\hline \multicolumn{5}{|c|}{ Other Clinical ICD-9/10 Diagnoses } \\
\hline $\begin{array}{l}\text { Drug } \\
\text { abuse/dependence }\end{array}$ & $29.0 \%(34,443)^{\mathrm{a}, \mathrm{b}}$ & $16.2 \%(7,347)^{\mathrm{a}, \mathrm{c}}$ & $10.8 \%(51,143)^{\mathrm{b}, \mathrm{c}}$ & $<0.0001$ \\
\hline $\begin{array}{l}\text { AUD + drug } \\
\text { abuse/dependence }\end{array}$ & $22.9 \%(27,191)^{\mathrm{a}, \mathrm{b}}$ & $12.0 \%(5,439)^{\mathrm{a}, \mathrm{c}}$ & $7.5 \%(35,347)^{b, c}$ & $<0.0001$ \\
\hline Mental disorder & $57.6 \%(68,290)^{\mathrm{a}, \mathrm{b}}$ & $60.6 \%(27,455)^{\mathrm{a}, \mathrm{c}}$ & $46.5 \%(220,537)^{b, c}$ & $<0.0001$ \\
\hline $\begin{array}{l}\text { AUD + mental } \\
\text { disorder }\end{array}$ & $26.2 \%(31,080)^{\mathrm{a}, \mathrm{b}}$ & $20.8 \%(9,439)^{\mathrm{a}, \mathrm{c}}$ & $13.8 \%(65,388)^{\mathrm{b}, \mathrm{c}}$ & $<0.0001$ \\
\hline Women $(n=61,808)$ & $\begin{array}{c}\text { Black } \\
30.0 \%(\mathrm{n}=18,460)\end{array}$ & $\begin{array}{c}\text { Hispanic } \\
8.2 \%(n=5,092)\end{array}$ & $\begin{array}{c}\text { White } \\
61.9 \%(\mathrm{n}=38,256)\end{array}$ & $P$ \\
\hline Age $(y)-$ mean $(S D)^{*}$ & $49.2(11.3)^{\mathrm{a}, \mathrm{b}}$ & $43.6(13.1)^{\mathrm{a}, \mathrm{c}}$ & $52.6(13.9)^{\mathrm{b}, \mathrm{c}}$ & $<0.0001$ \\
\hline
\end{tabular}




\begin{tabular}{|c|c|c|c|c|}
\hline \multicolumn{5}{|c|}{ Alcohol-Related Characteristics } \\
\hline Highest AUDIT-C & & & & $<0.0001$ \\
\hline 0 & $19.9 \%(3,664)^{a, b}$ & $13.6 \%(694)^{\mathrm{a}, \mathrm{c}}$ & $17.5 \%(6,692)^{b, c}$ & \\
\hline $1-2$ & $58.3 \%(10,762)^{b}$ & $61.4 \%(3,126)^{\mathrm{c}}$ & $58.6 \%(22,423)^{\mathrm{b}, \mathrm{c}}$ & \\
\hline $3-7$ & $16.0 \%(2,957)^{\mathrm{a}, \mathrm{b}}$ & $18.7 \%(952)^{\mathrm{a}}$ & $18.7 \%(7,139)^{b}$ & \\
\hline $8+$ & $5.8 \%(1,077)^{b}$ & $6.3 \%(320)^{\mathrm{c}}$ & $5.2 \%(2,002)^{b, c}$ & \\
\hline $\begin{array}{l}\text { Number of AUDIT-C } \\
\text { assessments - mean } \\
\text { (SD) }\end{array}$ & $9.2(4.3)^{\mathrm{a}, \mathrm{b}}$ & $7.8(4.1)^{\mathrm{a}, \mathrm{c}}$ & $8.9(4.3)^{b, c}$ & $<0.0001$ \\
\hline AUD & $14.9 \%(2,757)^{\mathrm{a}, \mathrm{b}}$ & $13.0 \%(662)^{\mathrm{a}}$ & $13.1 \%(5,005)^{b}$ & $<0.0001$ \\
\hline Cirrhosis $^{* * *}$ & $0.3 \%(53)$ & $0.3 \%(17)$ & $0.4 \%(152)$ & 0.1150 \\
\hline Neuropathy $^{* *}$ & $0.1 \%(13)$ & $0.0 \%(2)$ & $0.1 \%(31)$ & 0.5740 \\
\hline Cardiomyopathy $^{* *}$ & $0.0 \%(8)$ & $0.0 \%(0)$ & $0.0 \%(8)$ & 0.1589 \\
\hline Gastritis $^{* * *}$ & $0.1 \%(20)$ & $0.1 \%(5)$ & $0.1 \%(44)$ & 0.9326 \\
\hline Fatty liver disease $^{* *}$ & $0.1 \%(24)$ & $0.3 \%(14)$ & $0.2 \%(74)$ & 0.0651 \\
\hline Hepatitis $^{* *}$ & $0.2 \%(33)$ & $0.2 \%(12)$ & $0.3 \%(103)$ & 0.1182 \\
\hline
\end{tabular}




\begin{tabular}{|l|c|c|c|c|}
\hline \multicolumn{1}{|c|}{ Liver damage** } & $0.1 \%(26)$ & $0.1 \%(5)$ & $0.2 \%(57)$ & 0.6636 \\
\hline Other Clinical ICD-9/10 Diagnoses & $9.7 \%(495)^{\mathrm{a}, \mathrm{c}}$ & $11.2 \%(4,276)^{\mathrm{b}, \mathrm{c}}$ & $<0.0001$ \\
\hline Drug & $13.2 \%(2,436)^{\mathrm{a}, \mathrm{b}}$ & & $6.4 \%(2,452)^{\mathrm{b}}$ & $<0.0001$ \\
abuse/dependence & & & & \\
\hline AUD + drug & $8.5 \%(1,572)^{\mathrm{a}, \mathrm{b}}$ & $6.0 \%(304)^{\mathrm{a}}$ & $70.0 \%(26,773)^{\mathrm{b}, \mathrm{c}}$ & $<0.0001$ \\
\hline abuse/dependence & $71.3 \%(13,154)^{\mathrm{a}, \mathrm{b}}$ & $73.4 \%(3,739)^{\mathrm{a}, \mathrm{c}}$ & $12.4 \%(4,742)^{\mathrm{b}}$ & $<0.0001$ \\
\hline Mental disorder & $14.1 \%(2,607)^{\mathrm{a}, \mathrm{b}}$ & $12.5 \%(635)^{\mathrm{a}}$ & & \\
\hline
\end{tabular}

$\mathrm{SD}=$ standard deviation; AUDIT-C = Alcohol Use Disorders Identification Test - Consumption; AUD = alcohol use disorder.

*Number of observations with missing age: Black men $(n=5)$; Hispanic men $(n=8)$; White men $(n=42)$; Black women $(n=1)$; Hispanic women $(\mathrm{n}=1)$; White women $(\mathrm{n}=3) .{ }^{* *}$ Alcohol-specific diagnosis.

${ }^{\mathrm{a}}$ Black vs Hispanic pairwise comparison significant at $P<0.05 ;{ }^{b}$ Black vs White pairwise comparison significant at $P<0.05$; ${ }^{\mathrm{c}} \mathrm{Hispanic}$ vs White pairwise comparison significant at $P<0.05$. 
Table 2. Factors associated with AUD diagnosis, overall and stratified by sex.

\begin{tabular}{|c|c|c|c|c|c|c|}
\hline \multirow[b]{2}{*}{ Variables } & \multicolumn{2}{|c|}{ Overall $(\mathrm{n}=699,953)^{*}$} & \multicolumn{2}{|c|}{$\operatorname{Men}(n=638,150)^{*}$} & \multicolumn{2}{|c|}{ Women $(n=61,803)^{*}$} \\
\hline & aOR (95\% CI) & $P$ & aOR (95\% CI) & $P$ & aOR (95\% CI) & $P$ \\
\hline \multicolumn{7}{|l|}{$\begin{array}{l}\text { Race/Ethnicity } \mathrm{x} \text { highest } \\
\text { AUDIT-C score }\end{array}$} \\
\hline Black (ref=White) & $1.93(1.82,2.04)$ & $<0.0001$ & $2.04(1.92,2.17)$ & $<0.0001$ & $1.22(1.02,1.45)$ & 0.0273 \\
\hline Hispanic (ref=White) & $1.26(1.15,1.39)$ & $<0.0001$ & $1.28(1.16,1.41)$ & $<0.0001$ & $1.04(0.77,1.41)$ & 0.7983 \\
\hline Women (ref=men) & $0.67(0.65,0.69)$ & $<0.0001$ & - & - & - & - \\
\hline Age (10-yr increments) & $1.05(1.05,1.05)$ & $<0.0001$ & $1.05(1.05,1.06)$ & $<0.0001$ & $1.09(1.08,1.09)$ & $<0.0001$ \\
\hline \multicolumn{7}{|c|}{ Alcohol-Related Characteristics } \\
\hline Cirrhosis $^{* * * *}$ & $15.02(13.94,16.17)$ & $<0.0001$ & $14.84(13.77,16.00)$ & $<0.0001$ & $19.41(11.68,32.24)$ & $<0.0001$ \\
\hline Neuropathy $^{* * *}$ & $14.35(11.53,17.87)$ & $<0.0001$ & $13.80(11.08,17.19)$ & $<0.0001$ & $\begin{array}{c}176.80(17.68 \\
>999.99)\end{array}$ & $<0.0001$ \\
\hline Cardiomyopathy $^{* * * *}$ & $15.91(12.83,19.72)$ & $<0.0001$ & $15.71(12.66,19.50)$ & $<0.0001$ & $32.55(4.89,216.94)$ & 0.0003 \\
\hline Gastritis $^{* * *}$ & $30.70(19.92,47.30)$ & $<0.0001$ & $31.11(19.89,48.66)$ & $<0.0001$ & $21.67(4.07,115.46)$ & 0.0003 \\
\hline Fatty liver disease ${ }^{* * *}$ & $4.57(4.06,5.14)$ & $<0.0001$ & $4.59(4.08,5.18)$ & $<0.0001$ & $4.31(2.31,8.05)$ & $<0.0001$ \\
\hline
\end{tabular}




\begin{tabular}{|l|c|c|c|c|c|c|}
\hline Hepatitis & $14.41(11.47,18.11)$ & $<0.0001$ & $15.11(11.94,19.12)$ & $<0.0001$ & $4.99(1.97,12.61)$ & 0.0007 \\
\hline Liver damage $^{* * * *}$ & $8.38(6.82,10.29)$ & $<0.0001$ & $8.04(6.52,9.90)$ & $<0.0001$ & $22.01(7.24,66.97)$ & $<0.0001$ \\
\hline & Other Clinical ICD-9/10 Diagnoses \\
\hline Drug use disorder & $12.82(12.57,13.08)$ & $<0.0001$ & $12.70(12.44,12.97)$ & $<0.0001$ & $13.11(12.22,14.07)$ & $<0.0001$ \\
\hline Mental disorder & $3.19(3.14,3.25)$ & $<0.0001$ & $3.14(3.08,3.20)$ & $<0.0001$ & $5.06(4.51,5.67)$ & $<0.0001$ \\
\hline C-statistic & 0.91 & & 0.91 & & 0.91 \\
\hline
\end{tabular}

aOR=adjusted odds ratio; $95 \% \mathrm{CI}=95 \%$ confidence interval; AUDIT-C=Alcohol Use Disorders Identification Test - Consumption; $\mathrm{AUD}=$ alcohol use disorder. ${ }^{*}$ Number of observations with missing age: Black men ( $\left.\mathrm{n}=5\right)$; Hispanic men $(\mathrm{n}=8)$; White men ( $\left.\mathrm{n}=42\right)$;

Black women $(n=1)$; Hispanic women $(n=1)$; White women $(n=3){ }^{* *}$ Odds ratios displayed at mean highest AUDIT-C score (mean=3,

3, 2 for overall, men, and women, respectively). ${ }^{* * *}$ Alcohol-specific diagnosis. 
Figure 1a. Percentage of men with an AUD diagnosis by maximum AUDIT-C score, stratified by race/ethnicity (n=638,205).

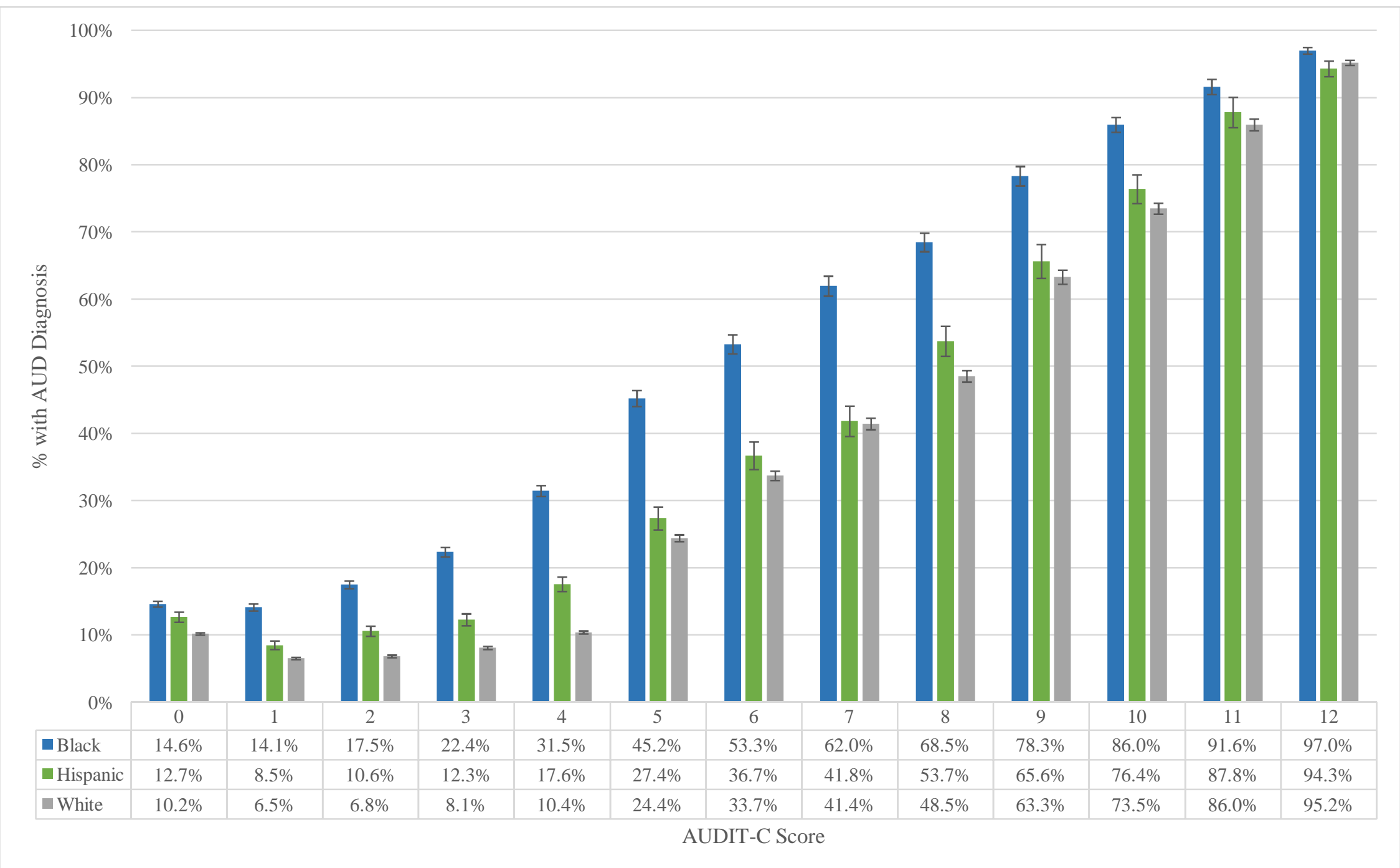

AUD=alcohol use disorder; AUDIT-C=Alcohol Use Disorders Identification Test - Consumption. 
Figure 1b. Percentage of women with an AUD diagnosis by maximum AUDIT-C score, stratified by race/ethnicity ( $\mathrm{n}=61,808)$.

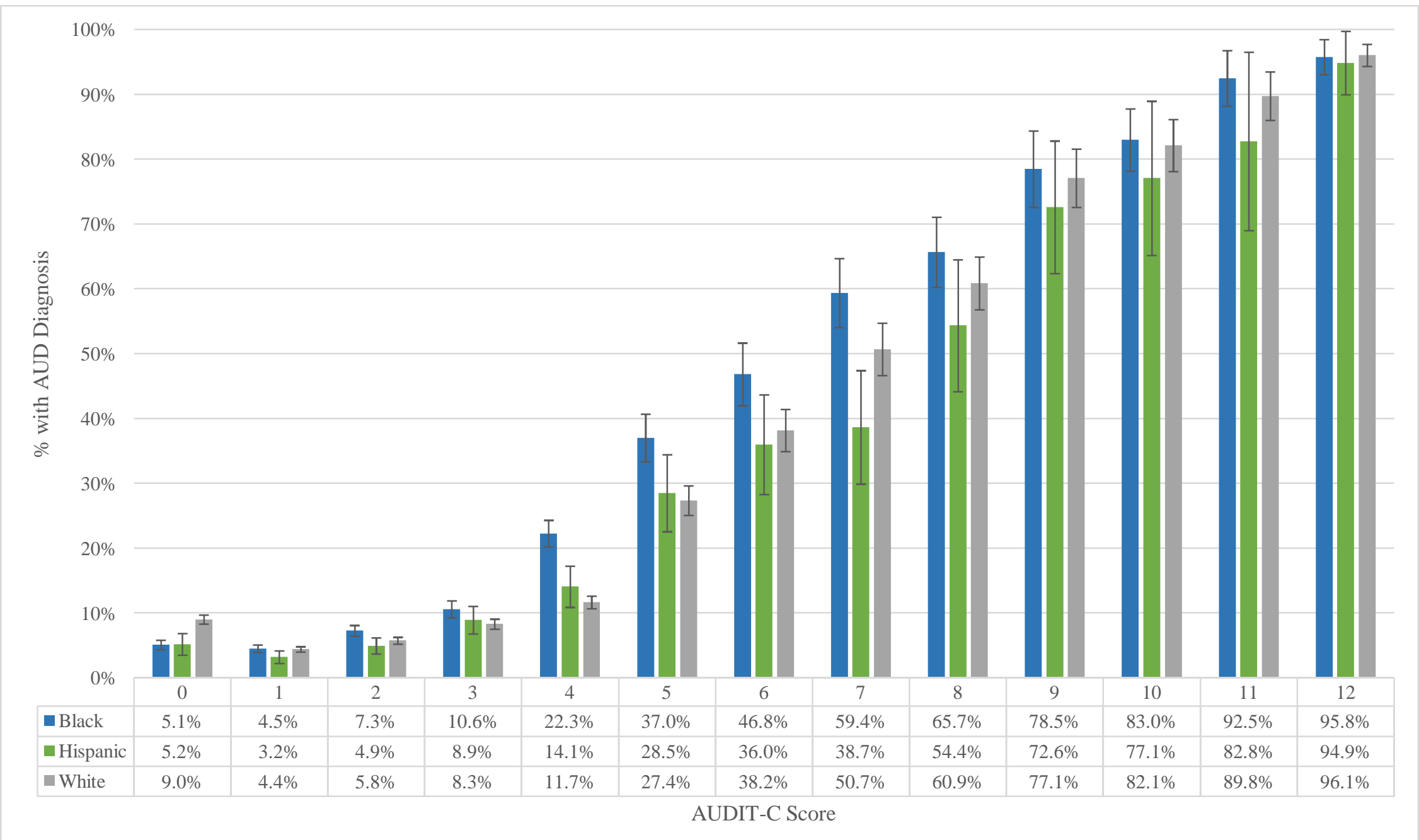

AUD=alcohol use disorder; AUDIT-C=Alcohol Use Disorders Identification Test - Consumption. 
Figure 2. Forest plot of adjusted odds ratios for the association between race/ethnicity and AUD diagnosis among men, stratified by maximum AUDIT-C score $(\mathrm{n}=612,112)$.
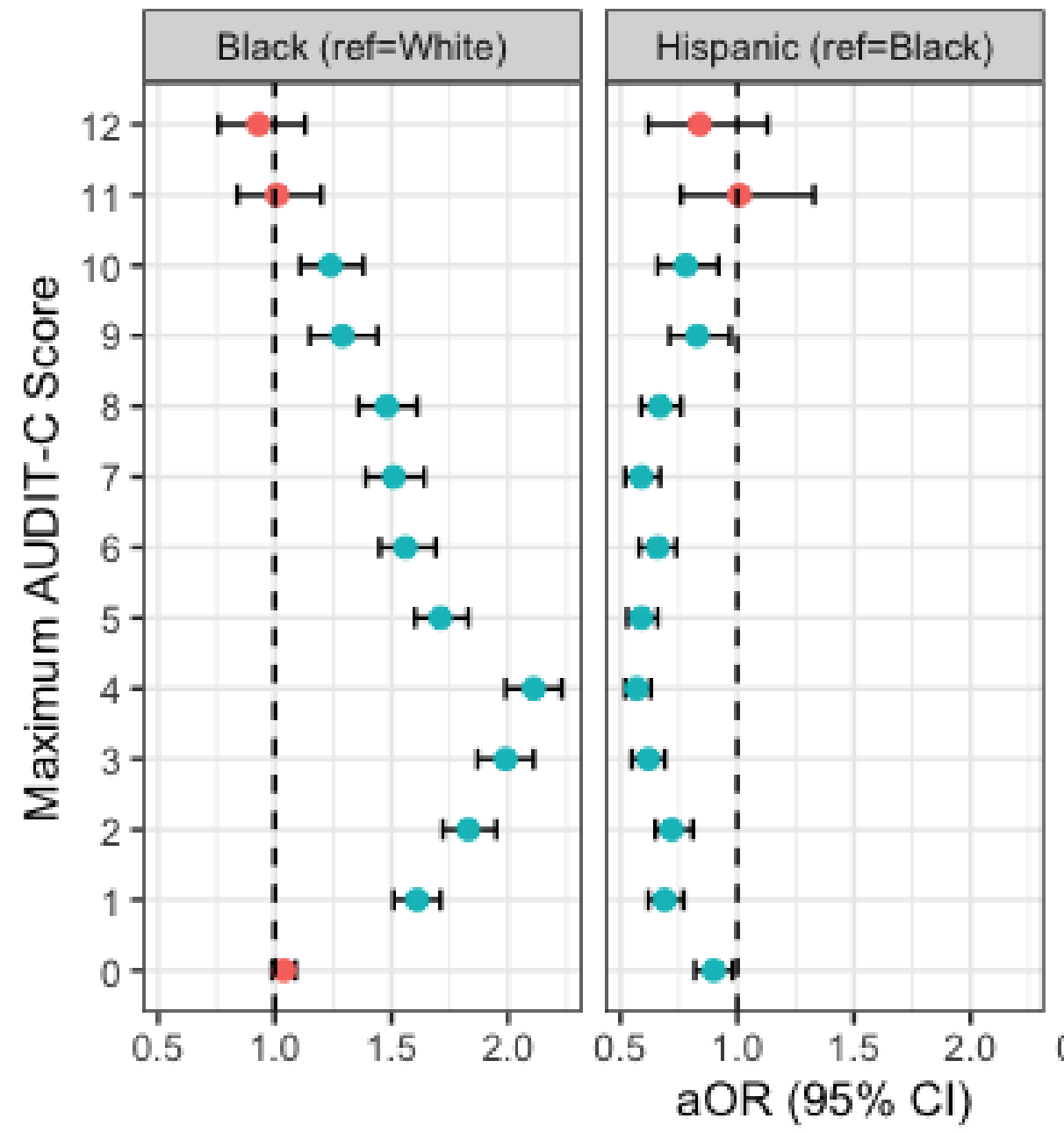

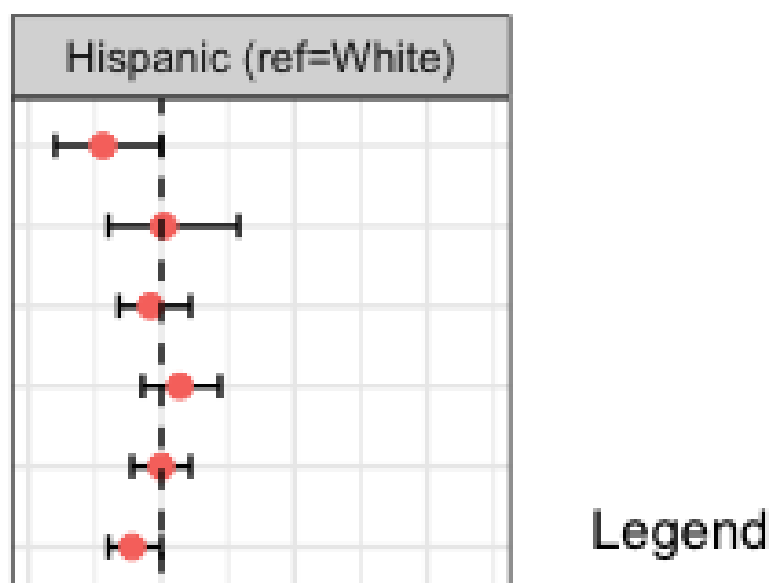

- Non-significant

- Significant 
AUD=alcohol use disorder; AUDIT-C=Alcohol Use Disorders Identification Test - Consumption; aOR=adjusted odds ratio; $95 \%$ $\mathrm{CI}=95 \%$ confidence interval.

Note: Models are adjusted for age at enrollment; drug abuse/dependence; mental disorder; alcohol-specific: cirrhosis, neuropathy, cardiomyopathy, gastritis, fatty liver disease, hepatitis, liver damage. 
medRxiv preprint doi: https://doi.org/10.1101/2021.07.14.21256113; this version posted July 18, 2021. The copyright holder for this preprint (which was not certified by peer review) is the author/funder, who has granted medRxiv a license to display the preprint in perpetuity.

\section{References}

1. Jutel A. Sociology of diagnosis: a preliminary review. Sociol Health Illn. 2009;31(2):278299. doi:10.1111/j.1467-9566.2008.01152.x

2. Glass JE, Mowbray OP, Link BG, Kristjansson SD, Bucholz KK. Alcohol stigma and persistence of alcohol and other psychiatric disorders: A modified labeling theory approach. Drug Alcohol Depend. 2013;133(2):685-692.

doi:10.1016/j.drugalcdep.2013.08.016

3. Keyes KM, Hatzenbuehler ML, McLaughlin KA, et al. Stigma and treatment for alcohol disorders in the united states. Am J Epidemiol. 2010;172(12):1364-1372. doi:10.1093/aje/kwq304

4. Gara MA, Minsky S, Silverstein SM, Miskimen T, Strakowski SM. A Naturalistic Study of Racial Disparities in Diagnoses at an Outpatient Behavioral Health Clinic. Psychiatr Serv. 2019;70(2):130-134. doi:10.1176/appi.ps.201800223

5. Schwartz RC. Racial disparities in psychotic disorder diagnosis: A review of empirical literature. World J Psychiatry. 2014;4(4):133. doi:10.5498/wjp.v4.i4.133

6. Alarcón RD. Culture, cultural factors and psychiatric diagnosis: Review and projections. World Psychiatry. 2009;8(3):131-139. doi:10.1002/j.2051-5545.2009.tb00233.x

7. Moskowitz GB, Stone J, Childs A. Implicit stereotyping and medical decisions:

Unconscious stereotype activation in practitioners' thoughts about African Americans. Am J Public Health. 2012;102(5):996-1001. doi:10.2105/AJPH.2011.300591

8. Dovidio JF, Fiske ST. Under the radar: how unexamined biases in decision-making processes in clinical interactions can contribute to health care disparities. Am J Public Health. 2012;102(5):945-952. 
medRxiv preprint doi: https://doi.org/10.1101/2021.07.14.21256113; this version posted July 18, 2021. The copyright holder for this preprint (which was not certified by peer review) is the author/funder, who has granted medRxiv a license to display the preprint in perpetuity.

All rights reserved. No reuse allowed without permission.

9. Fitzgerald C, Hurst S. Implicit bias in healthcare professionals: A systematic review. BMC Med Ethics. 2017;18(1):19. doi:10.1186/s12910-017-0179-8

10. Hall WJ, Chapman M V, Lee KM, et al. Implicit Racial/Ethnic Bias Among Health Care Professionals and Its Influence on Health Care Outcomes: A Systematic Review. Am J Public Health. 2015. doi:10.2105/AJPH.2015.302903

11. Williams EC, Gupta S, Rubinsky AD, et al. Racial/ethnic differences in the prevalence of clinically recognized alcohol use disorders among patients from the U.S. Veterans Health Administration. Alcohol Clin Exp Res. 2016;40(2). doi:10.1111/acer.12950

12. Williams EC, Lapham GT, Hawkins EJ, et al. Variation in documented care for unhealthy alcohol consumption across race/ethnicity in the Department of Veterans Affairs Healthcare System. Alcohol Clin Exp Res. 2012;36(9):1614-1622. doi:10.1111/j.15300277.2012.01761.x

13. Naps MS, Maass D, Kranzler HR, Smith R V, Ingram E, Oslin DW. Predictors of Treatment Referral After AUDIT-C Screening for Heavy Drinking. Addict Disord Their Treat. September 2018. doi:10.1097/adt.0000000000000134

14. Bensley KM, Harris AHS, Gupta S, et al. Racial/ethnic differences in initiation of and engagement with addictions treatment among patients with alcohol use disorders in the veterans health administration. J Subst Abuse Treat. 2017;73:27-34.

doi:10.1016/j.jsat.2016.11.001

15. Williams EC, Gupta S, Rubinsky AD, et al. Variation in receipt of pharmacotherapy for alcohol use disorders across racial/ethnic groups: A national study in the U.S. Veterans Health Administration. Drug Alcohol Depend. 2017;178:527-533.

doi:10.1016/j.drugalcdep.2017.06.011 
medRxiv preprint doi: https://doi.org/10.1101/2021.07.14.21256113; this version posted July 18, 2021. The copyright holder for this preprint (which was not certified by peer review) is the author/funder, who has granted medRxiv a license to display the preprint in perpetuity.

All rights reserved. No reuse allowed without permission.

16. Williams EC, Bradley KA, Gupta S, Harris AHS. Association Between Alcohol Screening Scores and Mortality in Black, Hispanic, and White Male Veterans. Alcohol Clin Exp Res. 2012;36(12):2132-2140. doi:10.1111/j.1530-0277.2012.01842.x

17. Bush K, Kivlahan DR, McDonell MB, Fihn SD, Bradley KA. The AUDIT Alcohol Consumption Questions (AUDIT-C): An Effective Brief Screening Test for Problem Drinking. Arch Intern Med. 1998;158(16):1789. doi:10.1001/archinte.158.16.1789

18. Bradley KA, Debenedetti AF, Volk RJ, Williams EC, Frank D, Kivlahan DR. AUDIT-C as a brief screen for alcohol misuse in primary care. Alcohol Clin Exp Res.

2007;31(7):1208-1217. doi:10.1111/j.1530-0277.2007.00403.x

19. Saunders JB, Aasland OG, Babor TF, De La Fuente JR, Grant M. Development of the Alcohol Use Disorders Identification Test (AUDIT): WHO Collaborative Project on Early Detection of Persons with Harmful Alcohol Consumption $\square$ II. Addiction. 1993;88(6):791804. doi:10.1111/j.1360-0443.1993.tb02093.x

20. Gaziano JM, Concato J, Brophy M, et al. Million Veteran Program: A mega-biobank to study genetic influences on health and disease. J Clin Epidemiol. 2016;70:214-223. doi:10.1016/j.jclinepi.2015.09.016

21. Harrington KM, Nguyen XMT, Song RJ, et al. Gender Differences in Demographic and Health Characteristics of the Million Veteran Program Cohort. Women's Heal Issues. 2019;29(Suppl 1):S56-S66. doi:10.1016/j.whi.2019.04.012

22. Hispanic Origin. https://www.census.gov/topics/population/hispanic-origin.html. Accessed April 9, 2021.

23. Erol A, Karpyak VM. Sex and gender-related differences in alcohol use and its consequences: Contemporary knowledge and future research considerations. Drug 
medRxiv preprint doi: https://doi.org/10.1101/2021.07.14.21256113; this version posted July 18, 2021. The copyright holder for this preprint (which was not certified by peer review) is the author/funder, who has granted medRxiv a license to display the preprint in perpetuity.

All rights reserved. No reuse allowed without permission.

Alcohol Depend. 2015;156:1-13. doi:10.1016/j.drugalcdep.2015.08.023

24. Stone J, Moskowitz GB. Non-conscious bias in medical decision making: what can be done to reduce it? Med Educ. 2011;45:768-776. doi:10.1111/j.1365-2923.2011.04026.x

25. Finucane TE, Carrese JA. Racial Bias in Presentation of Cases. J Gen Intern Med. $1990 ; 5: 120-121$.

26. Mulia N, Ye Y, Greenfield TK, Zemore SE. Disparities in alcohol-related problems among white, black, and Hispanic Americans. Alcohol Clin Exp Res. 2009;33(4):654-662. doi:10.1111/j.1530-0277.2008.00880.x

27. (US) $\mathrm{O}$ of the SG, (US) C for MHS, (US) NI of MH. Chapter 2 Culture Counts: The Influence of Culture and Society on Mental Health. 2001.

https://www.ncbi.nlm.nih.gov/books/NBK44249/. Accessed June 16, 2021.

28. Lin LA, B Bohnert AS, Blow FC, et al. Polysubstance use and association with opioid use disorder treatment in the US Veterans Health Administration. Addiction. 2021;116(1):96104. doi:10.1111/add.15116

29. Grant BF, Goldstein RB, Saha TD, et al. Epidemiology of DSM-5 alcohol use disorder results from the national epidemiologic survey on alcohol and related conditions III. JAMA Psychiatry. 2015;72(8):757-766. doi:10.1001/jamapsychiatry.2015.0584

30. Saha TD, Grant BF, Chou SP, Kerridge BT, Pickering RP, Ruan WJ. Concurrent use of alcohol with other drugs and DSM-5 alcohol use disorder comorbid with other drug use disorders: Sociodemographic characteristics, severity, and psychopathology. Drug Alcohol Depend. 2018;187:261-269. doi:10.1016/j.drugalcdep.2018.03.006

31. Kerker B, Leventhal J, Schlesinger M, Horwitz S. Racial and ethnic disparities in medical history taking: detecting substance use among low-income pregnant women. Ethn 
medRxiv preprint doi: https://doi.org/10.1101/2021.07.14.21256113; this version posted July 18, 2021. The copyright holder for this preprint (which was not certified by peer review) is the author/funder, who has granted medRxiv a license to display the preprint in perpetuity.

Disparities. 2006;16(1):28-34.

32. Kerker BD, Horwitz SM, Leventhal JM. Patients' characteristics and providers' attitudes:

Predictors of screening pregnant women for illicit substance use. Child Abus Negl.

2004;28(2):209-223. doi:10.1016/j.chiabu.2003.07.004

33. Section 2 PE Tables - Results from the 2019 National Survey on Drug Use and Health:

Detailed Tables, SAMHSA, CBHSQ.

https://www.samhsa.gov/data/sites/default/files/reports/rpt29394/NSDUHDetailedTabs20

19/NSDUHDetTabsSect2pe2019.htm. Accessed March 22, 2021.

34. Teeters J, Lancaster C, Brown D, Back S. Substance use disorders in military veterans:

prevalence and treatment challenges. Subst Abuse Rehabil. 2017;Volume 8:69-77.

doi:10.2147/sar.s116720

35. Keyes KM, Grant BF, Hasin DS. Evidence for a closing gender gap in alcohol use, abuse, and dependence in the United States population. Drug Alcohol Depend. 2008;93(1-2):2129. doi:10.1016/j.drugalcdep.2007.08.017

36. Peralta RL. Raced and Gendered Reactions to the Deviance of Drunkenness: A Sociological Analysis of Race and Gender Disparities in Alcohol Use. Contemp Drug Probl. 2010;37(3):381-415. doi:10.1177/009145091003700303

37. Abraham TH, Lewis ET, Drummond KL, Timko C, Cucciare MA. Providers' perceptions of barriers and facilitators to disclosure of alcohol use by women veterans. Prim Heal Care Res Dev. 2017;18(1):64-72. doi:10.1017/S1463423616000384

38. Lewis ET, Jamison AL, Ghaus S, et al. Receptivity to alcohol-related care among U.S. women Veterans with alcohol misuse. J Addict Dis. 2016;35(4):226-237.

doi:10.1080/10550887.2016.1171670 
medRxiv preprint doi: https://doi.org/10.1101/2021.07.14.21256113; this version posted July 18, 2021. The copyright holder for this preprint

(which was not certified by peer review) is the author/funder, who has granted medRxiv a license to display the preprint in perpetuity.

All rights reserved. No reuse allowed without permission.

39. Cucciare MA, Lewis ET, Hoggatt KJ, et al. Factors Affecting Women's Disclosure of Alcohol Misuse in Primary Care: A Qualitative Study with U.S. Military Veterans.

Women's Heal Issues. 2016;26(2):232-239. doi:10.1016/j.whi.2015.07.010

40. Chen JA, Glass JE, Bensley KMK, Goldberg SB, Lehavot K, Williams EC. Racial/ethnic and gender differences in receipt of brief intervention among patients with unhealthy alcohol use in the U.S. Veterans Health Administration. J Subst Abuse Treat. 2020;119. doi:10.1016/j.jsat.2020.108078 